\title{
Invertebrate colonization on artificial substrates in a coral reef at Gorgona Island, Colombian Pacific Ocean
}

\author{
Diego F. Lozano-Cortés ${ }^{1} \&$ Fernando A. Zapata ${ }^{1}$ \\ 1. Coral Reef Ecology Research Group, Department of Biology, Universidad del Valle. Calle 13 No. 100-00, A.A. 25360, \\ Cali,Colombia; diegoflc@gmail.com; fernando.zapata@correounivalle.edu.co
}

Recibido 18-X-2013. Corregido 20-XI-2013. Aceptado 19-XII-2013.

\begin{abstract}
Habitat colonization is a fundamental process in marine population dinamics and community ecology. Marine invertebrate colonization of artificial hard substrates and its spatial variation was studied over the course of one year at La Azufrada coral reef, Gorgona Island, Colombia. Five sets of artificial plates (terracotta and ceramic) were deployed parallel to the bottom in each of three reef zones (backreef, flat and slope). Plates were recovered after 12 months of their installation. The community that developed on the artificial substrate plates was composed of 24 taxa, among which corals were remarkably absent. Species richness on plates did not differ between reef zones, type of plate material or plate surfaces. The resulting community was dominated by barnacles (Balanus trigonus) with a mean density of $26787.8( \pm 47301.0)$ individuals $/ \mathrm{m}^{2}$ (mean \pm 1 S.D.). The density of this species was significantly higher on plates deployed on the reef slope than on the reef flat or back reef, and was lower on the upper than on the lower or lateral surfaces of plates. The dominance of B. trigonus on artificial plates during this experiment suggests a possible synergistic effect between its reproductive traits and competitive ability for space, which prevents the successful recruitment of other reef organisms such as corals. Rev. Biol. Trop. 62 (Suppl. 1): 161-168. Epub 2014 February 01.
\end{abstract}

Key words: Balanus trigonus, barnacles, coral reefs, Gorgona Island, invertebrates, colonization, spatial variation.

Coral reefs are invaluable sources of ecological, cultural, and economical richness (Wilkinson, 2004). These highly diverse ecosystems are constructed and dominated by sessile organisms that disperse via a planktonic larval stage during their early life history (Harrington et al., 2004). In sessile communities living on hard substrates, space on which to live is often the most important limiting resource (Jackson \& Buss, 1975; Jackson, 1977). Because unoccupied primary substrates are often rare on coral reefs, competition for space among sessile animals is common, often intense, and an important determinant of population and community ecology (Chornesky, 1989).

In the marine environment, areas of new and bare substrates available for colonization are either created naturally by disturbances that remove the organisms living on the benthos, or artificially by the immersion of structures in the body of water. In the latter case, artificial substrates have been used as a useful tool that allows the evaluation of the processes of settlement, recruitment, and community succession because they are easy to manipulate and follow over time (Perkol-Finkel \& Beneyahu, 2005). These new substrates are quickly colonized by a diverse assemblage of microbial organisms (i.e., biofilms) that change the biological, chemical, and physical properties of the substrate. These organisms often act as cues used by invertebrate larvae to locate or identify potential settlement sites allowing the development of abundant and diverse 
benthic communities (Keough, 1998, Burt, Bartholomew, Bauman, Saif \& Sale, 2009).

Studies using artificial settlement plates have found differences in the colonization of marine invertebrates over diverse kinds of substrates, reef zones and seasons (e.g., Harriot \& Fisk, 1987; Fitzhardinge \& Bailey-Broc, 1989; Field, Glassom \& Bythell, 2007). Additionally it has been reported that communities that develop on artificial settlement plates can vary over time depending on the plate's immersion time (Segal, Berenguerl \& Castro, 2012). Research involving these variables (substrates and immersion time) have not been common in the Tropical Eastern Pacific nor on Colombian Pacific coral reefs.

The objective of this research was to: 1) evaluate the effectiveness of two materials (terracotta and ceramic) as artificial substrates for the colonization of marine invertebrates, and 2) document its spatial variation in a Tropical Eastern Pacific coral reef at Gorgona Island, Colombia.

\section{MATERIALS AND METHODS}

Study area: Gorgona National Natural Park is a continental island located $35 \mathrm{~km}$ off the Colombian mainland $\left(2^{\circ} 58^{\prime} 00^{\prime \prime} \mathrm{N}\right.$ $78^{\circ} 11^{\prime} 24^{\prime \prime}$ W) within the area of influence of the Intertropical Convergence Zone. The eastern coast of the island has two main fringing reefs and several patch reefs dominated by branching corals of the genus Pocillopora (Glynn, Von Prahl \& Guhl, 1982). One of them, La Azufrada reef, is perhaps the largest reef of the Colombian Pacific and exhibits a degree of development comparable to that of the most developed coral reefs within the Tropical Eastern Pacific (TEP) region (Zapata 2001). Glynn et al. (1982), Zapata \& Vargas-Ángel (2003), Giraldo, Rodríguez-Rubio \& Zapata (2008) and Zapata, Rodríguez-Ramírez, CaroZambrano \& Garzón-Ferreira (2010) and Lozano-Cortés et al. (this issue) give details about coral formations, as well as oceanographic and physical conditions around Gorgona Island.
Colonization: To evaluate marine invertebrate colonization, five sets of artificial plates were deployed in each of three reef zones (backreef, flat and slope) at La Azufrada coral reef. Each set was composed of two plates, one of terracotta $(20 \times 20 \times 0.5 \mathrm{~cm})$ and one of ceramic $(20 \times 20 \times 1.0 \mathrm{~cm})$. The plates were oriented horizontally, parallel to and $10 \mathrm{~cm}$ above the bottom, and supported by an iron bar. The two plates in a set were $1 \mathrm{~m}$ from each other; while the distance between sets was $25 \mathrm{~m}$. Plates were recovered and examined after 12 months of their installation. This design allowed sessile organisms to colonize upper, lower, and lateral plate surfaces. The three surfaces were examined for invertebrates, which were counted and identified in the laboratory.

Before the recovery of the artificial plates, these were photographed to estimate the proportion of space occupied by bryozoans with software for digital image analysis (Scion Image). There is evidence that bryozoans overgrow recruits of other invertebrates on artificial substrates (Birkeland, 1977; Jackson, 1977). An analysis of variance for a completely randomized block design was carried out to evaluate the existence of significant differences in invertebrate density found between materials (2), plate surfaces (3), and reef zones (3). The statistical analysis was applied only to barnacle (B. trigonus) density because it was the dominant organism and other invertebrates did not occur with sufficient frequency. To compare bryozoan cover and species richness between materials, plate surfaces, and reef zones an ANOVA for a randomized block design was also done. Previous to all analysis, a Box-Cox transformation was applied to density data to fulfill the statistical assumptions

\section{RESULTS}

After one year, the plates supported a rich community of organisms that included 36,990 individuals $(62.5 \%$ of them on ceramic and $37.5 \%$ on terracotta) representing 24 taxa (Table 1). Barnacles were the most abundant on average (1233ind/plate), followed by serpulids 
TABLE 1

Invertebrates abundance found on artificial substrate plates in La Azufrada coral reef, Gorgona Island

\begin{tabular}{|c|c|c|c|c|c|}
\hline \multirow{2}{*}{ Taxon } & \multirow{2}{*}{ Class } & \multirow{2}{*}{ Family/Species } & \multicolumn{2}{|c|}{ Material } & \multirow{2}{*}{ TOTAL } \\
\hline & & & Terracotta & Ceramic & \\
\hline \multirow[t]{6}{*}{ Crustacea } & Maxillopoda & Balanus trigonus & 13727 & 22953 & 36680 \\
\hline & Malacostraca & Majidae sp. & 24 & 35 & 59 \\
\hline & & Megalops sp. & 2 & - & 2 \\
\hline & & Alpheus sp. & 9 & 20 & 29 \\
\hline & Polychaeta & Polychaeta sp. & 4 & 1 & 5 \\
\hline & & Serpulids sp. & 43 & 48 & 91 \\
\hline \multirow[t]{15}{*}{ Mollusca } & Bivalvia & Crepidula sp. & 52 & 4 & 56 \\
\hline & & Bivalve sp. & - & 1 & 1 \\
\hline & & Oyster sp. & 1 & 4 & 5 \\
\hline & & Brachydonta aff. playensis & - & 2 & 2 \\
\hline & & Mitrella aff. guttata & 1 & - & 1 \\
\hline & & Mitrella aff. elegans & - & 1 & 1 \\
\hline & Gastropoda & Hipponix panamensis & - & 9 & 9 \\
\hline & & Muricopsis zeteki & - & 2 & 2 \\
\hline & & Morula lugubris & - & 1 & 1 \\
\hline & & Rissoria stricta & - & 1 & 1 \\
\hline & Polyplacophora & Acantochitona avícula & 1 & 8 & 9 \\
\hline & & Acantochitona hirudiniformis & 1 & - & 1 \\
\hline & & Radsiella sp. & 1 & - & 1 \\
\hline & & Radsiella dispar & - & 3 & 3 \\
\hline & & Radsiella tenuisculpta & - & 3 & 3 \\
\hline \multirow[t]{2}{*}{ Echinodermata } & Echinoidea & Centrostephanus coronatus & - & 2 & 2 \\
\hline & & Ophiuridae sp. & 11 & 12 & 23 \\
\hline Chordata & Ascidiacea & Tunicate sp. & 4 & - & 4 \\
\hline TOTAL & & 24 & 13881 & 23109 & 36990 \\
\hline
\end{tabular}

(3.0ind/plate), bivalves (2.7ind/plate), crabs (1.2ind/plate), chitons and shrimps (0.6ind/ plate), brittle stars ( $0.4 \mathrm{ind} /$ plate), snails $(0.3 \mathrm{ind} /$ plate), tunicates, polychaetes and sea urchins ( $0.1 \mathrm{ind} /$ plate), and one species of bryozoa (mean cover $62.9 \mathrm{~cm}^{2} /$ plate). The abundance of $B$. trigonus differed marginally between reef zones, being greatest on the reef slope (ANOVA, $\mathrm{F}_{2.8}=4.2, \mathrm{p}=0.05$ ), and it was significantly greater on the lower than on the upper surface of plates $\left(\mathrm{F}_{2.8}=25.5, \mathrm{p}<0.0001\right.$; Fig. 1). However, the density of this barnacle did not differ between plate materials $\left(\mathrm{F}_{1.4}=2.3\right.$, $\mathrm{p}=0.20$ ).

Bryozoan cover varied significantly only between reef zones $\left(\mathrm{F}_{2.8}=6.6, \mathrm{p}=0.03\right)$ with a larger area occupied on plates deployed on the reef flat (Fig. 2). There was an evident preference of bryozoans to inhabit exclusively the lower surfaces of plates, where they were found independently of substrate material (for this reason, plate surface was not a factor in this statistical design). Finally, there were no significant differences in species richness among levels of the factors even though a greater number of species was found on lower surfaces of plates and on ceramic tiles (Fig. 3).

\section{DISCUSSION}

Artificial substrate plates were quickly colonized by a diverse assemblage of organisms. This colonization of newly available habitat has an important effect on the subsequent patterns of succession (Chapman, 2002). 

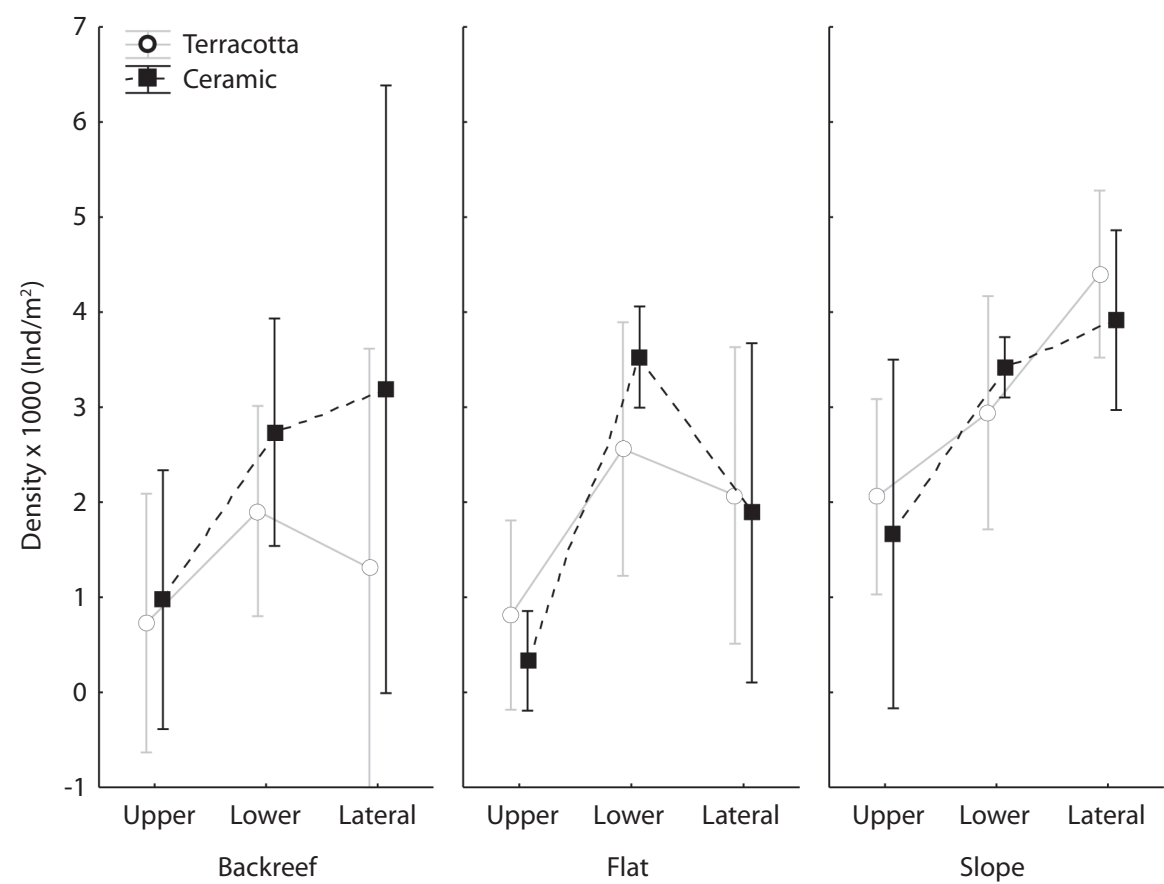

Fig. 1. Density of Balanus trigonus on three surfaces (upper, lower, lateral) of plates of two materials (terracotta, ceramic) in three zones (backreef, flat, slope) of La Azufrada coral reef, Gorgona Island.

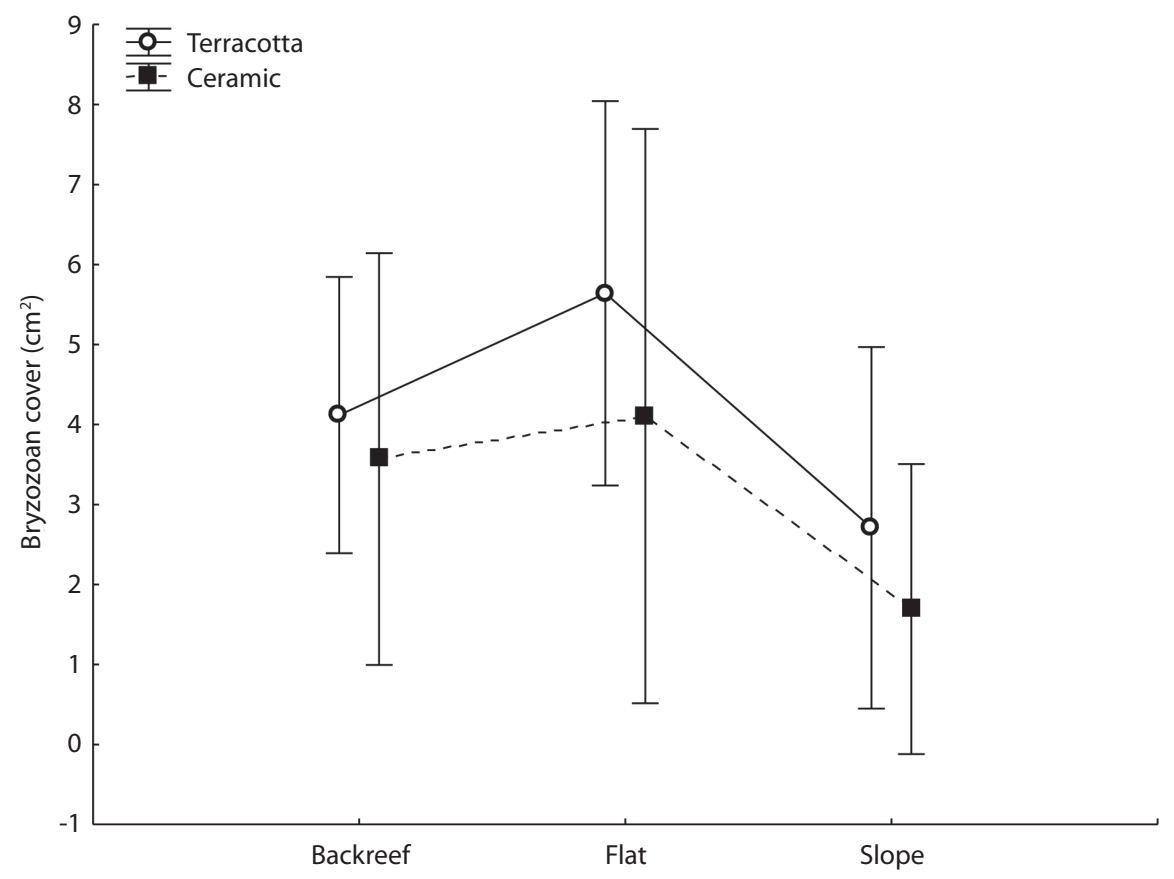

Fig. 2. Bryozoan cover on the lower surfaces of artificial plates of two materials (terracotta, ceramic) in three zones (backreef, flat, slope) of La Azufrada coral reef, Gorgona Island. 

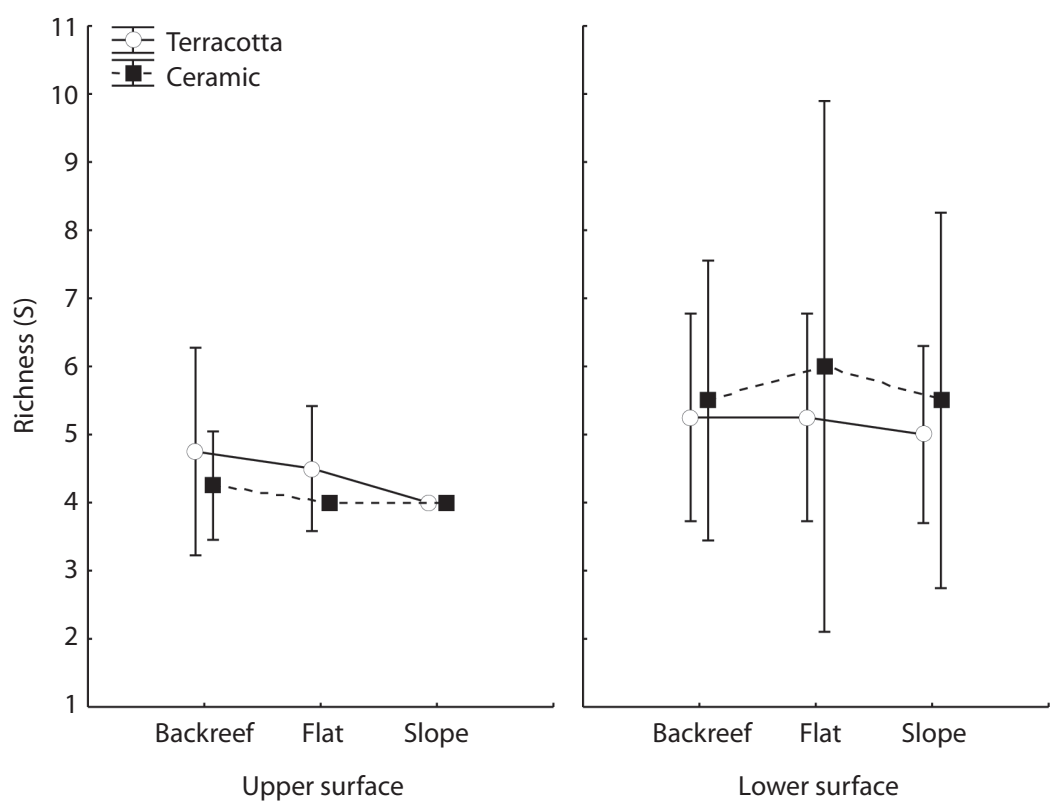

Fig. 3. Number of species that colonized one of two surfaces (upper, lower) of plates of two materials (terracotta, ceramic) in three zones (backreef, flat, slope) of La Azufrada coral reef, Gorgona Island.

Furthermore, patterns of recruitment and colonization contribute to the understanding of variation in species abundance and community dynamics. This is expected to be affected further by diverse factors associated with natural disturbances, habitat characteristics and the presence of other species (Jackson, 1977; Caffey, 1985; Fitzhardinge \& Bailey-Brock, 1989; Keough, 1998; Broitman et al., 2008).

It has been demonstrated that barnacle larve show strong settlement preferences for certain substrate topography (Wethey, 1986), though this was not seen in this study. There were no differences between the numbers of barnacles that colonized on both kinds of plates exhibiting different topographies (Fig. 1). Although these findings could be related to the broad range of substrates that barnacles colonize (Moore \& McPherson, 1963; Werner, 1967; LozanoCortés \& Londoño-Cruz, 2013), they contrast with previous studies on marine invertebrates that found preferences for specific substrate types (Fitzhardinge \& Bailey-Brock, 1989; Burt et al., 2009). While it has been suggested that benthic community composition can differ between substrates, there are other factors (e.g., immersion time, substrate complexity) that may also influence settlement. Some studies have reported that physical aspects such as tile orientation, method of placement or differences in recruitment patterns have a greater effect on benthic composition than substrate material (Field et al., 2007; Burt et al., 2009).

Spatial variability in recruitment is an important driver of community structure. Large-scale spatial variability has been attributed to factors that have the potential to alter larval distributions such as ocean currents, sea surface temperature or larval mortality by predation (Caffey, 1985; Gaines, Brown \& Roughgarden, 1985; Broitman et al., 2008). At smaller spatial scales (e.g., reef zones) mechanisms other than larval distributions are considered to be perhaps a major determinant of spatial variability. For example, Caffey (1985) and Gaines et al. (1985) found that recruitment on small spatial scales by the barnacles Tesseropora rosea and Balanus glandula was related to the temporal and spatial pattern of larval arrival to individual sites. 
In this study, there was significant spatial variation in barnacle colonization within the reef, with greater colonization on the reef slope. This result can be associated with the tendency of B. trigonus to inhabit deep habitats with low exposure to light (Werner, 1967; García \& Moreno, 1998; Glasby, 1999). The benthic community developed on the plates after 12 months was dominated by species of barnacles, turf algae and bryozoans. This community was similar to the one reported in another similar study in Panama (Birkeland, 1977). The latter author proposed that the dominance of these taxa was related to a suite of r-strategy life history traits present in these organisms (small size, fast growth, early reproductive maturity and short generation times). Such combination of traits leads to a rapid occupation of the available space and prevents the establishment of species such as corals, which tend to have a K-strategy suite of life history traits (large size, slow growth, long lifespan, late reproductive maturity and use of energy preferably in maintenance than in reproduction). In this sense, it is probable that this leads to a decrease in the success of coral recruitment, which has been characteristically low on artificial substrates in the TEP region (Wellington, 1982; Richmond, 1985; Glynn et al., 1996; Medina-Rosas et al., 2005; López-Pérez, Mora- Pérez \& LeyteMorales, 2007).

Variation in Balanus density between different habitats is considered to be a combination of larval availability in the plankton and water currents. For example, Gaines et al. (1985) suggested that it is more likely that variation in settler density could be a function of larval concentration instead of water or substrate characteristics. On the other hand, Elías \& Vallarino (2001) found that little water movement contributes to high rates of barnacle settlement because larvae are not dispersed. Additionally, in recent studies it has been suggested that the synergistic effects of temperature and salinity also have an influence in $B$. trigonus colonization (Thiyagarajan, Harder \& Qian, 2003; Broitman et al., 2008).
Similar to findings by Werner (1967), in this study bryozoans were the principal competitor for space against barnacles because these organisms seem to prefer the same microhabitat (i.e. lower plate surfaces). The fact that barnacles were capable of displacing bryozoans by undercutting (Rubin, 1985) explains their high density on the artificial plates even in the presence of a strong competitor. Both barnacles and bryozoans show a preference for downward facing surfaces exhibiting a pattern that had been previously reported on invertebrate colonization studies. Such pattern is explained as a strategy used by the larvae to avoid the adverse effects of sedimentation (Maughan, 2001).

The dominance of B. trigonus in the community that developed on the artificial substrate plates on coral reefs of Gorgona Island seems to be a result of the interaction between its reproductive traits (fast reproductive maturity, high reproductive rate and short larval periods; Werner, 1967; García \& Moreno, 1998, Thiyagarajan et al., 2003) and its competitive ability for space. However, it has been reported that the height of plates from the bottom may generate differences in the community structure developed due to variation in sedimentation levels, currents and possibly predation (Glasby, 1999). The employment of artificial substrate plates in future studies of recruitment, colonization and succession should consider both frequent and long-term surveying (i.e. monthly and yearly) as well as the effects of the structural characteristics of the artificial substrates deployed (e. g. spatial orientation).

\section{ACKNOWLEDGMENTS}

Field work was supported by the Coral Reef Ecology Research Group of Universidad del Valle, and the Special Administrative Unit of the System of National Natural Parks (UAESPNN). We want to thank James Carlton (Williams College) for his invaluable help in barnacle identification, Luz Ángela López de Mesa for her help with Polyplacophora and 
Juan Felipe Lazarus for his help with shrimps and crabs.

\section{RESUMEN}

La colonización de hábitat disponible es un proceso fundamental de la ecología de poblaciones y comunidades de organismos marinos. La colonización sobre sustratos artificiales por invertebrados y su variación espacial fue estudiada por un año en el arrecife coralino de La Azufrada, Isla Gorgona (Colombia). Cinco juegos de baldosas (terracota y grés) fueron dispuestos en tres zonas arrecifales (trasarrecife, planicie y talud). Las baldosas fueron recuperadas y examinadas después de 12 meses posteriores a su instalación. La comunidad desarrollada estuvo compuesta por 24 taxa siendo notable la ausencia de corales. No se encontraron diferencias en la riqueza de especies entre las zonas arrecifales, los materiales utilizados y las superficies de las baldosas. Las baldosas fueron dominadas por cirripedios (Balanus trigonus) con una densidad de 26787.8 ( \pm 47 301.0) ind $/ \mathrm{m}^{2}$ (media \pm 1 D.E). La densidad de esta especie fue significativamente más alta en el talud y menor en las superficies superiores. La dominancia de B. trigonus durante el experimento sugiere un posible efecto sinérgico entre sus características reproductivas y su habilidad competitiva por el espacio evitando que otros organismos, como los corales, recluten exitosamente.

Palabras clave: Trigonus Balanus, percebes, arrecifes de coral, Isla Gorgona, invertebrados, colonización, variación espacial.

\section{REFERENCES}

Birkeland, C. (1977). The importance of rate of biomass accumulation in early successional stages of benthic communities to the survival of coral recruits. Proceedings 3rd International Coral Reef Symposium, 1:15-21.

Broitman, B. R., Blanchette, C. A., Menge, B. A., Lubchenco, J., Krenz, C., Foley, M., Raimondi, P. T., Lohse, D. \& Gaines, S. D. (2008). Spatial and temporal patterns of invertebrate recruitment along the west coast of the United States. Ecological Monographs, 78: 403-421.

Burt, J., Bartholomew, A., Bauman, A., Saif, A. \& Sale P. (2009). Coral recruitment and early benthic community development on several materials used in the construction of artificial reefs and breakwaters. Journal of Experimental Marine Biology and Ecology, 373:72-78.

Caffey, J. M. (1985). Spatial and temporal variation in settlement and recruitment of intertidal barnacles. Ecological Monographs, 55: 313-332.
Chapman, M. G. (2002). Early colonization of shallow subtidal boulders in two habitats. Journal of Experimental Marine Biology and Ecology, 275: 95-116.

Chornesky, E. A. (1989). Repeated reversals during spatial competition between corals. Ecology, 70:843-855

Elías, R. \& Vallarino, E. (2001). The introduced barnacle Balanus glandula (Darwin) in the Mar del Plata port as a structuring species in the intertidal community. Investigaciones Marinas, 29: 37-46.

Field, S., D. Glassom, D. \& Bythell, J. (2007). Effects of artificial settlement plate materials and methods of deployment on the sessile epibenthic community development in a tropical environment. Coral Reefs, 26: 279-289.

Fitzhardinge, R. C. \& Bailey-Brock, J. H. (1989). Colonization of artificial reef materials by corals and other sessile organisms. Bulletin of Marine Science, 44: 567-579.

Gaines, S., Brown S. \& Roughgarden, J. (1985). Spatial variation in larval concentrations as a cause of spatial variation in settlement for the barnacle Balanus glandula. Oecología, 67: 267-272.

García C. \& Moreno, I. (1998). Recruitment, growth, mortality and orientation patterns of Balanus trigonus (Crustacea: Cirripedia) during succession on fouling plates. Scientia Marina, 62:59-64.

Giraldo, A., Rodríguez-Rubio, E. \& Zapata, F. (2008). Condiciones oceanográficas en Isla Gorgona, Pacífico oriental tropical de Colombia. Latin American Journal of Aquatic Research, 36: 121-128.

Glasby, T. M. (1999). Interactive effects of shading and proximity to the seafloor on the development of subtidal epibiotic assemblages. Marine Ecology Progress Series, 190: 113-124.

Glynn, P. W., Von Prahl, H. \& Guhl, F. (1982). Coral reefs of Gorgona Island, with special reference to corallivores and their influence on community structure and reef development. Anales del Instituto de Investigaciones Marinas de Punta de Betín, 12: 185-214.

Glynn, P. W., Colley, S. B., Gassman, N. J., Black, K., Cortés, J. \& Maté, J. L. (1996). Reef coral reproduction in the eastern Pacific: Costa Rica, Panamá, and Galápagos Island. III. Agariciidae. Marine Biology, 125: 579-601.

Harrington, L., Fabricius, K., De'ath, G. \& Negri, A. (2004). Recognition and selection of settlement substrata determine post-settlement survival in corals. Ecology, 85: 3428-3437.

Harriott, V. \& Fisk, D. (1987). A comparison of settlement plate types for experiments on the recruitment of scleractinian corals. Marine Ecology Progress Series, 37: 201-208. 
Jackson, J. (1977). Competition on marine hard substrata: The adaptive significance of solitary and colonial strategies. American Naturalist, 111: 743-767.

Jackson, J. \& Buss, L. (1975). Allelopathy and spatial competition among coral reef invertebrates. Proceedings of the National Academy of Sciences, 72: 5160-5163.

Keough, M. J. (1998). Responses of settling invertebrate larvae to the presence of established recruits. Journal of Experimental Marine Biology and Ecology, 231: 1-19.

López-Pérez, R., Mora- Pérez, M. \& Leyte-Morales, G. (2007). Coral (Anthozoa: Scleractinia) recruitment at Bahías de Huatulco, Western México: Implications for coral community structure and dynamics. Pacific Science, 61: 355-369.

Lozano-Cortés, D. F. \& Londoño-Cruz, E. (2013). Checklist of barnacles (Crustacea; Cirripedia: Thoracica) from the Colombian Pacific. Marine Biodiversity, 43(4). doi: 10.1007/ s12526-013-0175-2.

Lozano-Cortés, D. F., Giraldo, A. \& Izquierdo, V. (2014). Short-term assessment of the sediment deposition rate and water conditions during a rainy season on La Azufrada coral reef, Gorgona Island, Colombia. Revista de Biología Tropical, 62 (Suppl. 1): 107-116.

Maughan, B. (2001). The effects of sedimentation and light on recruitment and development of a temperate, subtidal, epifaunal community. Journal of Experimental Marine Biology and Ecology, 256: 59-71.

Medina-Rosas, P., Carriquiry, J. D. \& Cupul-Magaña, A. L. (2005). Reclutamiento de Porites (scleractinia) sobre sustrato artificial en arrecifes afectados por El Niño 1997-98, en Bahía de Banderas, Pacífico mexicano. Ciencias Marinas, 31: 103-109.

Moore, H \& McPherson, B. (1963). Colonization of the Miami area by the barnacle Balanus trigonus Darwin and a note on its occurrence on the test of an echinoid. Bulletin of Marine Science, 13: 418-421.

Perkol-Finkel, S. \& Y. Benayahu. (2005). Recruitment of benthic organisms onto a planned artificial reef: shifts in community structure one decade post-deployment. Marine Environmental Research, 59: 79-99.
Richmond, R. H. (1985). Variations in the population biology of Pocillopora damicornis across the Pacific. Proceedings of the fifth International Coral Reef Congress, 6: 101-106.

Rubin, J. A. (1985). Mortality and avoidance of competitive overgrowth in encrusting bryozoa. Marine Ecology Progress Series, 23: 291-299.

Segal, B., Berenguer1, V. \& Castro C. (2012). Experimental recruitment of the Brazilian endemic coral Mussismilia braziliensis and conditioning of settlement plates. Ciencias Marinas, 38:1-10.

Thiyagarajan, V., Harder, T. \& Qian, P. (2003). Combined effects of temperature and salinity on larval development and attachment of the subtidal barnacle Balanus trigonus Darwin. Journal of Experimental Marine Biology and Ecology, 287: 223-236.

Wellington, G. M. (1982). Depth zonation of corals in the Gulf of Panama: control and facilitation by resident reef fishes. Ecological Monographs, 52: 224-241.

Werner, W. E. (1967). The distribution and ecology of the barnacle Balanus trigonus. Bulletin of Marine Science, 17: 64-84.

Wethey, D. (1986). Ranking of settlement cues by barnacle larvae: Influence of surface contour. Bulletin of Marine Science, 39: 393-400.

Wilkinson, C. (2004). Status of coral reefs of the world: 2004. Global Coral Reef Monitoring Network. Australian Institute of Marine Science, 557.

Zapata, F. A. (2001). Formaciones coralinas de Isla Gorgona. In L. M. Barrios \& M. López-Victoria (Eds.), Gorgona marina: Contribución al conocimiento de una isla única (pp. 27-40). INVEMAR-Serie Publicaciones Especiales No. 7. Santa Marta, Colombia.

Zapata, F. A. \& Vargas-Ángel, B. (2003). Corals and coral reefs of the Pacific coast of Colombia. In J. Cortés (Ed.), Latin America coral reefs (pp. 419-447). Elsevier Science B. V., Amsterdam, Netherlands.

Zapata, F. A., Rodríguez-Ramírez, A., Caro-Zambrano, C. \& Garzón-Ferreira, J. (2010). Mid-term coral-algal dynamics and conservation status of a Gorgona Island (Tropical Eastern Pacific) coral reef. Revista de Biología Tropical, 58 (Suppl. 1): 81-94. 